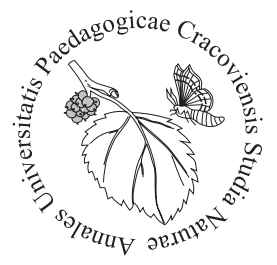

Jaromír Vašíček ${ }^{1,2 *}$, Andrej Baláži ${ }^{1}$, Vladimír Parkányi ${ }^{1}$, Miroslav Bauer ${ }^{1,3}$

${ }^{1}$ Institute for Farm Animal Genetics and Reproduction, Research Institute for Animal Production Nitra, NAFC, Lužianky, Slovak Republic, *jaromir.vasicek@gmail.com

${ }^{2}$ Department of Biochemistry and Biotechnology, Faculty of Biotechnology and Food Science, Slovak University of Agriculture, Nitra, Slovak Republic

${ }^{3}$ Department of Botany and Genetics, Faculty of Natural Sciences, Constantine the Philosopher University, Nitra, Slovak Republic

\title{
Different MACS sorting strategies for the enrichment of Lin- (CD34+ CD45) hematopoietic progenitor cells: preliminary study
}

Magnetic-activated cell sorting (MACS) has become a standard method for cell separation in many different fields. Numerous publications have demonstrated its use, from lab bench to the clinic, both small to large scale, from abundant cells to rare cells with complex phenotypes, and from human and mouse cells to many other species (Bosio et al., 2009). There are various magnetic cell separation systems currently available. They differ principally in two features: the composition and size of the magnetic particles used for cell labelling (Miltenyi et al., 1990; Ugelstad et al., 1998) and the mode (positive isolation - enrichment or negative isolation - depletion) of magnetic separation.

At present, animal stem cells are widely used in the biomedical research. Since rabbit is genetically very close to human, rabbit hematopoietic stem/progenitor cells (HSC/HPC) could be a precious animal model cell line for the study of human hematopoietic disorders. However, among the published studies, there is none available that describes either this type of rabbit cells or their isolation itself. Cryopreservation of HSC/HPC for human therapeutic use in hematopoietic stem cell banks has been carried out for more than 30 years. Three types of HSC/HPC harvests from bone marrow, mobilized peripheral blood, and umbilical cord blood (Watt et al., 2007) are now routinely obtained by the MACS enrichment of CD34 positive cells. The same principle could be used for the isolation and cryopreservation of rabbit HSC/HPC. However, currently, there is no substantial data on the isolation and/or enrichment of rabbit hematopoietic stem cells, or on the detection of rabbit CD34+ cells. In the few published studies, mainly anti-human CD34 antibodies (Vašíček et al., 2018) were 
used, due to the unavailability of specific anti-rabbit CD34 antibodies in the market. On the other hand, HSC/HPC are defined as lineage negative cells that do not express lineage commitment markers typical for mature hematopoietic cells, including $\mathrm{T}$ and B cells, monocytes/macrophages, granulocytes, erythrocytes, and their committed precursors (Gallacher et al., 2000). Thus, mature cells expressing lineage commitment markers can be easily depleted from the heterogeneous mixture of hematopoietic cells (Cheng et al., 2008) in order to enrich HSC/HPC.

Therefore, the aim of this preliminary study was to isolate rabbit HSC/HPC via removing mature hematopoietic cells that express CD45 (common leukocyte antigen) from the rabbit peripheral blood and bone marrow.

Material and methods

Isolation of cells from rabbit blood and bone marrow

Mononuclear cells from rabbit peripheral blood (PBMCs) and bone marrow (BMMCs) were isolated from 3 young (5 months-old does) and clinically health rabbits of the NZW line as described previously (Vašíček et al., 2016; 2018).

Indirect immunomagnetic sorting of $\mathrm{CD} 45^{+} \mathrm{PBMCs}$ and $\mathrm{BMMCs}$ Briefly, mononuclear cells were aliquoted into prepared tubes and incubated with anti-rabbit CD45 monoclonal antibody (L12/201, mouse IgG1; Biorad, UK) for 15 minutes on ice. After washing, samples were incubated with Anti-Mouse IgG1 MicroBeads (Miltenyi Biotec, Germany) according to the producer's manual. Three different types of sorting strategy available by AutoMACS Pro Separator (Miltenyi Biotec, Germany) were used in the experiments: 1) Depletes - Depletion in sensitive mode I for the removal of cells with normal antigen expression, if purity is the highest priority or for the removal of cells with low antigen expression; 2) Depl025 - Depletion in sensitive mode III for the removal of cells with low antigen expression, special program for very sensitive depletion; and, 3) Posselds - Positive selection in sensitive mode, double-column program for the isolation of cells with frequencies lower than $5 \%$ and low antigen expression. Control samples were analysed for CD45 expression but not sorted.

Flow cytometry After MACS sorting, the APC-conjugated Labelling Check Reagent (LCR; Miltenyi Biotec, Germany), which binds to the microbeads, was used to control the sorting efficiency. Moreover, control samples (unsorted cells) and both MACS fractions (negative and positive) were incubated with another clone of anti-rabbit CD45 (ISC18A, mouse IgG2a; WSU, USA) and appropriate secondary anti-mouse IgG2a-FITC antibody (eBioscience, Austria). 7-AAD (eBioscience, Austria) was used in order to ex- 
clude debris and dead cells from the analysis. Labelled cells before and after sorting were evaluated using a FACSCalibur flow cytometer (BD Biosciences, USA). At least 50.000 events (cells) were analysed in each sample. Double positive cells $\left(\mathrm{CD} 45^{+} \mathrm{LCR}^{+}\right)$ in MACS fractions served as an indicator of the sorting (depletion) efficiency in negative fractions.

\section{qPCR analysis of CD34 expression}

Total RNA isolation and cDNA synthesis from the control (unsorted) samples and both $\mathrm{CD} 45^{-}$and $\mathrm{CD} 45^{+}$fractions as well as quantitative polymerase chain reaction (qPCR) were performed according to Vašíček et al. (2017). Since rabbit CD34 has predicted two transcript variants, we used universal primers that comprise both known transcripts (Vašíček et al., 2017).

\section{Results}

Flow cytometry results are summarised in table 1. According to the obtained data, isolated rabbit PBMCs showed more than $98 \%$ positivity for CD45 antigen. On the other hand, only $70 \%$ of fresh rabbit BMMCs were positive for CD45. Double staining $\left(\mathrm{CD} 45^{+} \mathrm{LCR}^{+}\right)$of separated cells revealed the best depletion efficiency in the negative fractions that were sorted using Depl025 mode for both PBMCs and BMMCs (about 10 and $3 \%$, respectively).

Tab. 1. Sorting efficiency of different MACS strategies in terms of removing CD $45^{+}$cells from the sorted samples assessed by flow cytometry as the percentage of $\mathrm{CD} 45^{+} \mathrm{LCR}^{+}$cells [\%]

\begin{tabular}{|c|c|c|c|c|c|c|c|c|c|}
\hline \multirow[b]{2}{*}{ Sample } & \multicolumn{3}{|c|}{ Depletes } & \multicolumn{3}{|c|}{ Depl025 } & \multicolumn{3}{|c|}{ Posselds } \\
\hline & 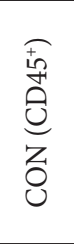 & 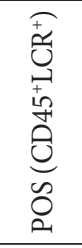 & 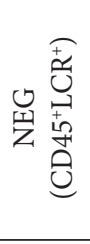 & 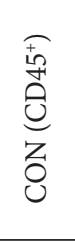 & 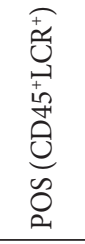 & 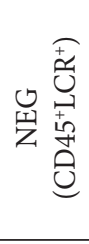 & 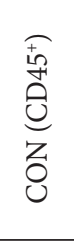 & 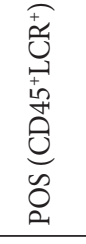 & 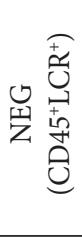 \\
\hline PBMCs & 98.8 & 93.4 & 37.4 & 99.1 & 95.5 & 10.0 & 98.8 & 95.4 & 44.6 \\
\hline BMMCs & 67.3 & 94.4 & 22.4 & 65.7 & 92.6 & 2.7 & 75.8 & 98.2 & 32.1 \\
\hline
\end{tabular}

Note: CON - control (unsorted) fresh sample analysed for the initial expression of CD45, POS - positive fraction, NEG - negative fraction, LCR - Labelling Check Reagent

qPCR analyses were used to evaluate the relative expression of CD34 in the control and sorted samples. The highest CD34 expression within the negative fractions were found in the PBMCs sample sorted using Depl025 mode in comparison to the control and positive fractions or, in general, within the used sorting strategies (Fig. 1). On 


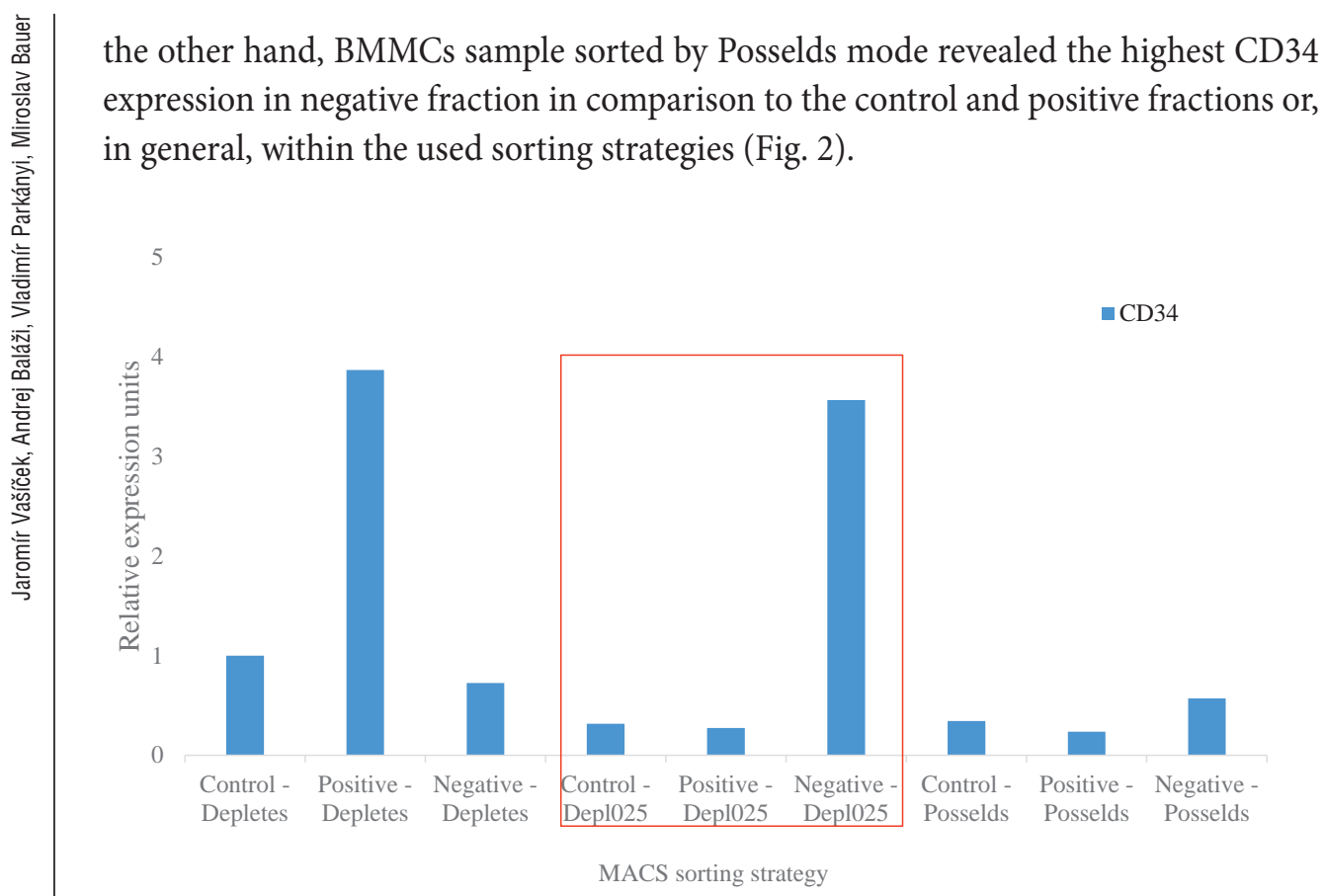

Fig. 1. Relative expression of CD34 in control (unsorted) and sorted PBMCs normalised to B2M (beta-2-microglobulin)

$$
2
$$

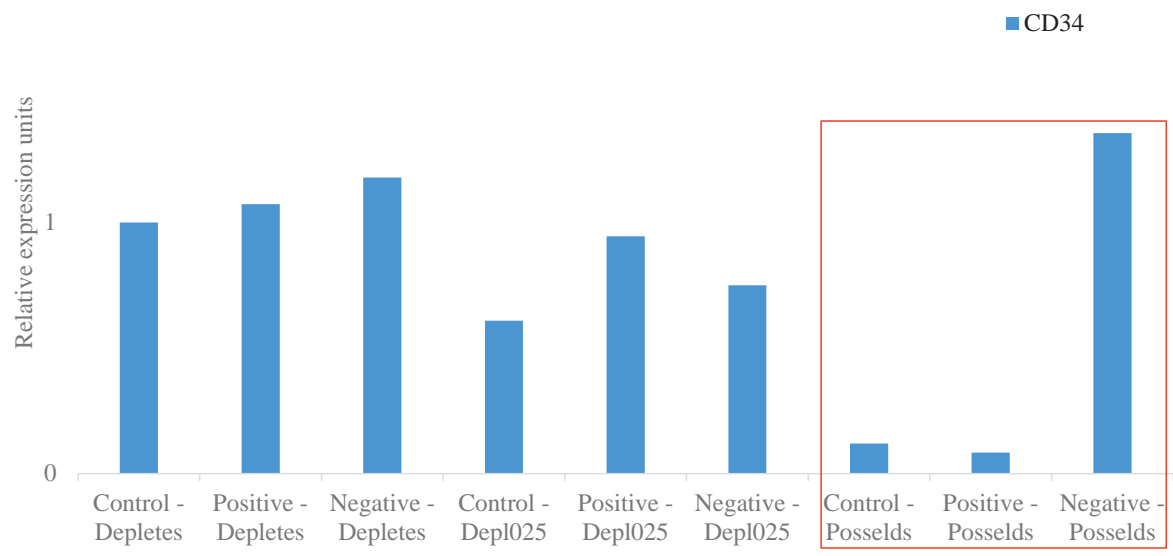

MACS sorting strategy

Fig. 2. Relative expression of CD34 in control (unsorted) and sorted BMMCs normalised to B2M (beta-2-microglobulin) 
We chose three different MACS sorting strategies for the negative or positive selection of $\mathrm{CD} 45^{+}$cells in order to obtain the highest sorting efficiency or the maximum removal of mature hematopoietic cells $\left(\mathrm{CD} 45^{+}\right)$from the sample. According to the producer's manual, these strategies differed mainly in the sample loading rate and the number of used magnetic columns: 1) Depletes - one column mode with loading rate $1 \mathrm{~mL} / \mathrm{min}$; 2) Depl025 - one column mode with loading rate $0.25 \mathrm{~mL} / \mathrm{min}$; and, 3) Posselds - two column mode with loading rate $1 \mathrm{~mL} / \mathrm{min}$ for each column. Thus, the sorting efficiency of the used modes could differ according to the sample loaded as well as the level of desired antigen expression.

In this preliminary study, we assessed the sorting or depletion efficiency of MACS strategies used as the percentage of $\mathrm{CD} 45^{+} \mathrm{LCR}^{+}$cells. The best removal of $\mathrm{CD} 45^{+}$cells in both PBMCs and BMMCs samples was obtained using Depl025 mode (Tab. 1). So, we might assume that negative fractions (CD45) obtained by this mode can be enriched for $\mathrm{CD}_{3} 4^{+}$cells. This finding strongly agreed with qPCR analysis of rabbit PBMCs sorted by this mode, since the highest relative expression of CD34 was noticed in the negative fraction in comparison to other negative fractions or the control and positive fraction within the sample (Fig. 1). However, the highest relative expression of CD34 in BMMCs was observed in the negative fraction of the sample sorted by a Posselds mode (Fig. 2) in comparison to other negative fractions or the control and positive fractions within the sample.

Although there are presently no any published studies focusing on the enrichment of rabbit Lin $\left(\mathrm{CD} 34^{+} \mathrm{CD} 45^{-}\right)$cells, this technique based on the depletion of cells with lineage commitment markers is widely used for the purification of mouse (Ema et al., 2006) or human (Cheng et al., 2008) hematopoietic stem and progenitor cells.

Conclusions

This preliminary study demonstrated the possibility to obtain a cell population from rabbit PBMCs or BMMCs that is enriched for $\mathrm{CD} 34^{+}$cells. The best MACS sorting strategy according to the relative expression of CD34 antigen in enriched (negative fractions) were Depl025 for rabbit PBMCs or Posselds for BMMCs. As far as we know, this is the first published study focusing on the enrichment of rabbit HSC/HPC $\left(\mathrm{CD} 34^{+}\right)$cells using the removal of $\mathrm{CD} 45^{+}$cells. However, further experiments are required in order to prove these preliminary results.

This work was supported by the grants: APVV-14-0348 and VEGA 1/0160/18.

Acknowledgement 


\section{References}

Bosio, A., Huppert, V., Donath, S., Hennemann, P., Malchow, M., Heinlein, U.A.O. (2009). Isolation and Enrichment of Stem Cells. Advances in Biochemical Engineering/Biotechnology, 114, 23-72. DOI: 10.1007/10_2008_38

Cheng, P., Corzo, C.A., Luetteke, N., Yu, B., Nagaraj, S., Bui, M.M., Ortiz, M., Nacken, W., Sorg, C., Vogl, T., Roth, J., Gabrilovich, D.I. (2008). Inhibition of dendritic cell differentiation and accumulation of myeloid-derived suppressor cells in cancer is regulated by S100A9 protein. Journal of Experimental Medicine, 205(10), 2235-2249. DOI: 10.1084/jem.20080132

Ema, H., Morita, Y., Yamazaki, S., Matsubara, A., Seita, J., Tadokoro, Y., Kondo, H., Takano, H., Nakauchi, H. (2006). Adult mouse hematopoietic stem cells: purification and single-cell assays. Nature Protocols, 1(6), 2979-2987. DOI: 10.1038/nprot.2006.447

Gallacher, L., Murdoch, B., Wu, D.M., Karanu, F.N., Keeney, M., Bhatia, M. (2000). Isolation and characterization of human $\mathrm{CD} 34 \mathrm{Lin}^{-}$and $\mathrm{CD} 34^{+} \mathrm{Lin}^{-}$hematopoietic stem cells using cell surface markers AC133 and CD7. Blood, 95, 2813-2820.

Miltenyi, S., Müller, W., Weichel, W., Radbruch, A. (1990). High gradient magnetic cell separation with MACS. Cytometry, 11, 231-238. DOI: 10.1002/cyto.990110203

Ugelstad, J., Prestvik, W., Stenstad, P., Kilaas, L., Kvalheim, G. (1998). Selective cell separation with monosized magnetizable polymer beads. In: W. Andrä, H. Nowak (eds.), Magnetism in medicine - a handbook. Weinheim: Wiley, 473-490. DOI: 10.1002/masy.19880170113

Vašíček, J., Bauer, M., Baláži, A., Chrenek, P. (2017). Expression of CD34 in different passages of rabbit endothelial progenitor cells. Animal Physiology 2017 - Proceedings of International Conference, Košice: SAV Ústav fyziológie hospodárskych zvierat, 81.

Vašíček, J., Kováč, M., Baláži, A., Bauer, M., Chrenek, P. (2016). Phenotypic analysis of rabbit mesenchymal stem cells using flow cytometry and RT-PCR. Slovak Journal of Animal Science, 49(4), 160.

Vašíček, J., Shehata, M., Schnabl, S., Hilgarth, M., Hubmann, R., Jäger, U., Bauer, M., Chrenek, P. (2018). Critical assessment of the efficiency of CD34 and CD133 antibodies for enrichment of rabbit hematopoietic stem cells. Biotechnology Progress. [In Press]. DOI:10.1002/btpr.2659

Watt, S.M., Austin, E., Armitage, S. (2007). Cryopreservation of Hematopoietic Stem/Progenitor Cells for Therapeutic Use. In: J.G. Day, G.N. Stacey (eds.), Methods in Molecular Biology: Cryopreservation and Freeze-Drying Protocols. Totowa, NJ: Humana Press Inc., 237-259. DOI: 10.1007/978-1-59745362-2_17

Abstract

Magnetic-activated cell sorting (MACS) has become a standard method for the isolation of hematopoietic stem/progenitor cells (HSC/HPC) in human or mouse models using CD34 antibodies. However, at present, there is no useable CD34 antibody that could be successfully used for the selection of rabbit HSC/HPC. Therefore, the aim of this preliminary study was to remove all mature cells $\left(\mathrm{CD} 45^{+}\right)$from the heterogeneous mixture of rabbit peripheral blood and bone marrow mononuclear cells (PBMCs and BMMCs) in order to enrich these cell populations for the $\mathrm{CD} 34^{+}$cells. Briefly, cells were incubated with a CD45 antibody and proper magnetic microbeads. Three different MACS sorting strategies were used in the experiment that differed mainly in the sample loading rate and the number of used magnetic columns. Control (unsorted) and sorted cells were assessed for the sorting efficiency (\% of double positive cells for CD45 and Labelling Check Reagent - LCR) by flow cytometry and for the relative expression of CD34 antigen by qPCR. According to flow cytometry, Depl025 mode showed the best sorting efficiency in terms of the lowest percentages of $\mathrm{CD} 45^{+} \mathrm{LCR}^{+}$cells for rabbit PBMCs as well as BMMCs. qPCR analysis confirmed this mode as the best in terms of the relative CD34 expression for rabbit PBMCs. However, a higher relative expression of CD34 in BMMCs was obtained by another mode - Posselds. In conclusion, this study demonstrates a possible 
enrichment of rabbit $\left(\mathrm{CD} 34^{+}\right) \mathrm{HSC} / \mathrm{HPC}$ by the magnetic depletion of mature hematopoietic $\left(\mathrm{CD} 45^{+}\right)$cells. Key words: CD34, CD45, flow cytometry, hematopoietic stem cells, MACS, qPCR, rabbit

Received: [2018.05.30]

Accepted: [2018.11.22]

\section{Różne strategie sortowania MACS do wzbogacania hematopoetycznych komórek progenitorowych Lin- $\left(\mathrm{CD} 34^{+} \mathrm{CD} 45^{\circ}\right)$ : badania wstępne \\ Streszczenie}

W modelu ludzkim lub mysim, sortowanie komórek aktywowane magnetycznie (MACS) stało się standardową metodą izolacji hematopoetycznych komórek macierzystych/progenitorowych (HSC/HPC) z użyciem przeciwciał CD34. Obecnie jednak nie ma użytecznego przeciwciała CD34, które mogłoby być z powodzeniem zastosowane do selekcji króliczego HSC/HPC. Dlatego celem tego wstępnego badania było usunięcie wszystkich dojrzałych komórek $\left(\mathrm{CD} 45^{+}\right)$z heterogennej mieszaniny krwi obwodowej królika i jednojądrzastych komórek szpiku kostnego (PBMC i BMMC), aby wzbogacić ich populacje dla komórek CD34+. Komórki inkubowano z przeciwciałem CD45 i odpowiednimi mikrokulkami magnetycznymi. W eksperymencie zastosowano trzy różne strategie sortowania MACS, które różniły się głównie szybkością ładowania próbki i liczbą użytych kolumn magnetycznych. Kontrolne (nieposortowane) i posortowane komórki oceniano pod względem wydajności sortowania (\% podwójnie dodatnich komórek dla CD45 i odczynnika do sprawdzania znakowania - LCR), za pomocą cytometrii przepływowej i względnej ekspresji antygenu CD34 przez qPCR. Zgodnie z cytometrią przepływową tryb Depl025 wykazał najlepszą skuteczność sortowania pod względem najniższego odsetka komórek $\mathrm{CD}_{4} 5^{+} \mathrm{LCR}^{+}$dla PBMC królika, jak również BMMC. Analiza qPCR potwierdziła ten tryb jako najlepszy do oceny względnej ekspresji CD34 dla PBMC królików. Najwyższą względną ekspresję CD34 w BMMC uzyskano w innym trybie - Posselds. Podsumowując, niniejsze badanie demonstruje możliwe wzbogacenie HSC/HPC królika (CD34+) przez magnetyczne zubożenie dojrzałych komórek krwiotwórczych $\left(\mathrm{CD} 45^{+}\right)$.

Słowa kluczowe: CD34, CD45, cytometria przepływowa, hematopoetyczne komórki macierzyste, MACS, qPCR, królik

\section{Information on the authors}

Jaromír Vašíček https://orcid.org/0000-0003-4144-8584

Expert in the field of the farm animal reproduction and the preservation of animal genetic resources. His specializations are the following: $1^{\text {st }}$ - the study of the farm animal male generative cells, $2^{\text {nd }}$ - research on farm animal somatic stem cells, and $3^{\text {rd }}$ - the application of the biotechnological methods for the conservation of animal genetic resources via stem cell banking.

\section{Andrej Baláži}

Expert in the field of animal cell isolation, magnetic cell separation, flow cytometry, cell culture, and animal reproduction.

\section{Vladimír Parkányi}

Senior researcher with long-time experiences in the field of cytogenetics of farm animal somatic and generative cells with skills in the field of animal cell magnetic separation, PCR techniques, and ELISA.

\section{Miroslav Bauer}

Expert in molecular biology experienced in genetic markers of farm animals, rDNA and gene cloning, PCR, RT-qPCR, DNA sequencing and bioinformatics. 